\title{
Ammatillisen erityisopetuksen pedagogiikasta ja didaktiikasta
}

\begin{abstract}
Hautamäki, Jarkko. 1981. Ammatillisen erityisopetuksen pedagogiikasta ja didaktiikasta. Aikuiskasvatus 1, 3-4, 88-94. - Artikkelissa tarkastellaan ammatillista erityisopetusta lähtien siitä, että ammatillisen toiminnan erittelyn tulee olla myös erityisryhmien opetuksen perusta. Tämän pohjalta kritikoidaan konkreettisuuden ylikonkretisoivia tulkintoja, jotka jättävät puolitiehen ammatillisten kokonaisuuksien etsinnän ammatillisen erityisopetuksen opetussuunnitelmallisen kehittelyn perustana. Samalla vaikeutuu myös itse opetus- ja oppimistapahtuman ohjaus, minkä keskeisin edellytys olisi normaalia tarkempi oppimisen ja opetuksen ehtojen erittely. Erääksi harkittavaksi ratkaisumahdollisuudeksi esitetään työkonekokonaisuuden idea, mitä samalla käytetään ainakin hypoteettisenä "'apuviivana" tarkasteltaessa psykologian ja pedagogiikan näkökulmien eroa ja sovittamismahdollisuuksia. Psykologinen näkökulma perustuu suuntautumisteoriaan, jota täydennetään Neisserin skeema-teorian avulla. Psykologisesta näkökulmasta otetaan esiin ennakointi sellaisena prosessina, joka ammatillisessa erityisopetuksessa voitaisiin pyrkiä muodostamaan, koska sen avulla kyettäisiin vaikuttamaan opettavien taitojen yleiseen käyttöön. Suuntautumisteorian avulla on tarkasteltu myös oppimisvaikeuksien diagnosointia.
\end{abstract}

\section{Ammatillisen erityisope- tuksen opetussuunnitelmalli- sista kysymyksistä}

Normaalipalveluiden ensisijaisuús on hyväksytty kehitysvammahuollon kehittämisperiaatteeksi. Yleisiä palveluita tulee kehittää myös erityisryhmien käytettäviksi.

Ammatillisessa koulutuksessa on luonnollisesti otettu huomioon erityisryhmiä ja ammatillista erityisopetusta on järjestetty. Tänä päivänä on kysymys toiminnan laajentamisesta ja laadullisesta kehittämisestä.

Erityisryhmien ammatillisen opetuksen toteuttaminen edellyttää erittelyä ja suunnittelua. Erityisryhmien kohdalla ammatillinen opetus ei ole yleisten didaktisten periaatteiden suoraa soveltamista opetustavoitteista supistamalla ja opetusta konkretisoimalla. Pikemminkin on kysymys ammatillisen koulutuksen luonteen täsmentämisestä ja ammatillisen toiminnan erittelystä.

Esityksessä lähdetään liikkeelle yleisistä ajatusmalleista, joiden on usein katsottu riittävän ammatillisen erityisopetuksen toteuttamisessa. Tavoitteena on eritellä tilannetta niin pitkälle, että eräät psykologis-pedagogiset lähtökohdat alkavat tulla näkyviin. Niiden kautta etsitään ratkaisuja kehitysvammaisten ammatillisen koulutuksen kysymyksiin.

\subsection{Konkreettisuus ja opetus- suunnitelmallinen ongelma}

Konkreettisuus on ammatillisen erityisopetuksen yleisimmin esitetty didaktinen ratkaisuperiaate. Siihen sisältyy kuitenkin vaara ylikorostaa konkreettisuutta ja jättää erittelemättä ammatillisen koulutuksen tavoitteet. Konkreettisuus asetetaan nimittäin usein vastakohdaksi teoreettisuudelle. Sitä konkreettisuuden ei kuitenkaan tarvitse merkitä. Didaktisesti ja psykologisesti konkreettisuus tarkoittaa ennenmuuta sitä, ettă yleiset periaatteet voivat esiintyä käytännöllisissä ja esineellisissä tilanteissa: momentti ilmenee vivuissa, painovoima liikkeessä, geometria esineissä. Kaikissa koneissa, laitteissa, työkaluissa ilmenevät jotkin yleiset toiminnalliset periaatteet.

Kaikissa työkoneissa ilmenevät koneen toiminnalliset osat jossain muodossa: on voimanlähde, on siirtolaite, on työstöosa, on työkappale. Opetuksessa konkreettisuus tarkoittaisi rajoittumista vain yksittäisten koneiden piirteisiin selvittämättä koneiden yleistä 'toiminnallista arkkitehtuuria'. Vastaavasti yleisen mukaanotto merkitsee sekä yksittäisen laitteen omaksumista että myös siinä ilmenevän yleisen omaksumista. Kehitysvammaisten ammatillisessa opetuksessa tämä tarkoittaisi mm. sitä, että koneiden opettamiseen on liitettävä luokkaopetusta, jossa selvitetään koneiden eri osien olemassaolo ja tunnistamisedellytykset. (Hautamäki \& Riikonen 1980) 
Ammatilliseen erityisopetukseen sisältyy eräitä opetussuunnitelmallisia korostusvaihtoehtoja. Voidaan lähteä liikkeelle yleisistä ammatillisen koulutuksen tavoitteista ja muodoista. Kurssi rakennetaan yhtenäiseksi kokonaisuudeksi taivata työ tavoitteena. Toinen vaihtoehto on konkreettisuuden ja käytännöllisyyden korostaminen. Tähän ajatusmalliin liian vaikeiden osien poisruksiminen arvioidun vaikeuden perusteella - liittyy usein ajattelutapa, jonka mukaan ammatillinen opetus soveltuu erityisryhmille hyvin siksi, että siinä voidaan olla niin konkreettisia. Kuitenkin, jos käytännöllisyyteen ei liitetä halutun lopputuloksen tarkastelua, niin vaarana on ylikäytännöllinen, yksittäistaitojen opetus. Tuloksena on taitojen epämääräinen ryhmä, josta ei muodostu ammatillista osaamista eikä siten luoda edellytyksiä myöskään itsenäisyydelle ja persoonalliselle kehitykselle.

Ihmiset saattavat viihtyä käden taitoja vaativissa askareissa, mutta ammatillisen erityisopetuksen on tähdättävä kauemmaksi. On lähdettävä liikkeelle normaalin ammatillisen opetuksen tavoitteista. Kurssin tavoitteena saattaa olla supistettu ammattitaito - esimerkiksi suojatöiden edellyttämät valmiudet - mutta ydinalueeltaan suorituksen on oltava korkeatasoinen. Ilman tätä kehitysvammaisten työhön sijoittuminen ei ole mahdollista (Hautamäki 1979).

\subsection{Ammatillisten kokonaisuuksien määrittely}

Taitavan työn opetussuunnitelmallinen ongelma on kokonaisuuksien tunnistaminen ja huomioonottaminen. Kokonaisuudet ovat ongelma siksi, että ne eivät esiinny konkreettisina ja käsinkosketeltavina asioina. Ammatilliset kokonaisuudet ovat ajattelupsykologisesti jo teoreettisia yleistyksiä. Ne tarkoittavat yleisesti sitä, mikä yhdistää yksittäiset suoritukset työn tavoitteisiin. Toisella tapaa puhuen kysymys on siitä, miten yksittäiset operaatiot muodostetaan tekojen ja toiminnan osiksi.

Höylän käyttö on yksittäisenä suorituksena ns. operaatio. Se on osa ammatillista toimintaa silloin, kun oppilas osaa yhdistää sen ammatilliseen tapahtumaan pinnantasoitus - höylä on eräs keino tasoittaa pintaa ja on olemassa joukko muitakin tapoja. Näiden eri tapojen - hiekkapaperi, tasohöylä, hiomakone jne - on oltava oppilaan mielessä rinnakkaisina operaatioina, joiden käyttöönotto riippuu tilanteen ehdoista. Ehdotkin tulisi opetuksessa ottaa käsittelyyn.

Hautamäki \& Riikonen (1980) esittelevät mm. puutyö- ja metallityökorteissa' eräistä laitteista kuusi yleistä funktiota tai puolta, jotka kaikki toteutuvat eri muodoissa eri koneilla, mutta psykologisesti ovat osa yhtenäistä kokonaisuutta esimerkiksi koneen käynnistämistä (sivut 72-76).

Ammatillisten kokonaisuuksien erittely tuottaa esiin yleisessä muodossa opetuksen vaatimukset. Tämä ei vielä ole kuitenkaan pedagoginen ratkaisu. Voidaan puhua erikseen opetussuunnitelmallisesta ja opetuksellisesta ongelmasta. Opetussuunnitelmallisen ongelman ratkaisu on opetusta, opetuksen ongelman ratkaisu on oppimista. Tämä kahden tason erottelu on ammatillisen erityisopetuksen kehittämisen kannalta tärkeä (kts yleisesti Hautamäki 1978), vaikkakaan sen ei tarvitse olla esillä enää ammatillisen erityisopetuksen päivärutiineissa tai työnohjauksessa.

Ammatillisten kokonaisuuksien etsinnässä käytetään hyväksi työnanalyysiä, jossa eritellään todellisia ammattitehtäviä (Singleton 1978; Youngman 1978).

Kokonaisuuksien etsinnän ongelmat erityisopetuksessa ovat liittyneet siihen, että tulokset on pyritty suoraan muuttamaan oppiaineiksi; joskus myös on ollut niin, että työnanalyysia ei ole juuri käytetty oppiaine-ratkaisuissa. Oppiaineiden ongelmana on se, että niitä ei voida sellaisinaan käyttää erityisopetuksen perustana - jos erilaisista oppiaineista otetaan pois vaikeasti omaksuttavat osat, niin tuloksena on psykologisesti vielä vaikeammin vastaanotettava osien ja yksityiskohtien joukko. Tästä syystä erityisopetuksen kokonaisuuden ongelman ratkaisua on haettava hieman toisella tavalla.

Työkonekokonaisuus on eräs ratkaisu, jonka kautta on mahdollista tavoitella kokonaisuuksia ja kuitenkin löytää erilaisille asioille nähtävät ja kosketeltavat vastineet. Useimpiin ammatillisen erityisopetuksen ammattitehtäviin liittyvät oleellisesti koneiden ja laitteiden käyttötavat. Laitteiden hallinta merkitsee siten ainakin taitavan suorituksen välttämättömien ehtojen täyttymistä, ei ehkä vielä riittäviä. Ammatillisen kokonaisajattelun kannalta laitteiden ongelma on se, miten varmistaa sellaisten taitojen ja tietojen muodostuminen, jotka ylittävät vain koneiden käytössä ilmenevät tarpeelliset osaamiset. On kohtuullisen helppo turvata koneiden käyttö. Vaikea on sen opettaminen, miten jokin työsuoritus jaetaan erilaisille koneille ja missä järjestyksessä työ olisi tehtävä. 


\subsection{Työkoneiden pedagogisesta käsittelystä}

Väliaskeleeksi ammatillisen koulutuksen tavoitteista niiden psykologiseen toteuttamiseen on edellä esitetty työkonekokonaisuus. Väliaskel on tarpeen, jotta saataisiin aikaan sellainen tarkasteluyksikkö, jota voidaan eritellä sekä yleiseltä ammatillisen opetuksen että erityiseltä psykologiselta kannalta. Ilman tällaista apuyksikköä - koulugeometrian apupiirrosta psykologisen näkökulman yhdistäminen pedagogiseen näkökulmaan tuottaa mekanistisia ratkaisuja.

Työkalujen käytön oppiminen voidaan ajatella sellaisen taidon oppimiseksi, jossa ilmenevät omaksumisen lainmukaisuudet ja jossa samalla yhdistyvät konkreettisuus ja teoreettisuus. Leontjevin (1979) sanoin työkalu jäljittelee ihmisen omia ominaisuuksia - englantilainen Bernal on puhunut ihmisen ulottuvuuksista. Oleellista työkaluissa on niiden käyttösuunnitelma, jossa kiteytetään laitteen ominaisuudet, työstökappaleen ominaisuudet sekä laitteen käyttäjän tavoitteet ja taidot.

\section{Opetussuunnitelman psykologisesta käsittelystä}

\subsection{Oppimisen mallin esittely}

Keskeisenä tavoitteena on nyt jatkaa tarkastelua psykologian näkökulmasta ja jättää tähän asti kehitelty ammatillisen opetuksen näkökulma väliaikaisesti sivummalle. Tavoitteena on erityisesti esittää malli, jonka avulla voidaan tarkastella opetuksen järjestämistä ammatillisessa erityisopetuksessa. Mallin avulla tulisi voida eritellä opittavan toiminnan omaksumisen ne vaiheet, jotka luonteensa puolesta edellyttävät erilaista muodostavaa ja opettavaa käsittelyä (kts ns. kuvailevasta ja normatiivisesta erittelystä Hautamäki 1978). Malli rakennetaan suuntautumisteorian käsittein (Galperin 1980; Hautamäki 1978; Hautamäki \& Riikonen 1980; Häyrynen \& Hautamäki 1977). Samantapainen lähestyminen, tosin erilaiseen tilanteeseen sovellettuna, on ns. sisäisten mallien teoria (Mikkonen et al 1980) ja yleisesti eräät 'kyberneettiset' lähestymistavat.

Suuntautumisteorian mukaan jokaisessa psyykkisessä toiminnassa on kolme erillistä osaa. Ensimmäinen on orientoituminen tehtävän olosuhteisiin ja toimintasuunnitelman kehittely. Toinen on suoritusvaihe. Kolmas on tulosten tai välituloksen vertaaminen asetet- tuun tavoitteeseen ja tarvittavien korjausten teko. Kyse on kontrollivaiheesta.

\section{Suuntautuminen ja tavoitteenasettelu}

Kysymys on taitavan suorituksen keskeisestä vaiheesta ja inhimillisen toiminnan ehkä tärkeimmästä tunnusmerkistä. Suuntautuminen liittyy siihen, että tilanteen 'ärsykkeisiin' ei reagoida automaattisesti ja mekaanisesti. Harkiten ja vakain tuumin selvitetään mistä tilanteessa on kysymys. Sen perustalta jäsennetään reitti tavoitteeseen. Tavoitteesta muodostetaan ennakoiva mielikuva.

Vaiheeseen liittyy päätavoitteen erittely ja sen aikaansaamisen edellytysten arviointi: tunnistetaan toiminnan kulkuedellytykset ja seuraanto. Selvitetään, mitkä ovat osatoimintojen kohteet ja suoritustavat. Hahmotellaan etukäteen se, miten toiminnan kulkua tulee arvioida ja millainen on lopputilan haluttu laatu.

Suuntautumisella tarkoitetaan psykologisesti toimintatilanteen ehtojen kokonaisuutta, jonka huomioonottaminen turvaa toiminnan onnistumisen. Kehitysvammaisten monet suoritusvaikeudet voidaan palauttaa usein suuntautumisvaiheen ja tavoitteenasettelun puutteisiin ja suuntautumisen opetuksellisen käsittelyn laiminlyöntiin. Tässä ilmenee ns. konkreettisen opetuksen vaikeuksien syy: ns. yleisesittely, jonka psykologinen funktio on olla suuntaava, jätetään antamatta, koska uskotaan tai epäillään, että kehitysvammaiset oppilaat eivät siitä kuitenkaan mitään hyötyisi. Tämän mukaisesti opetuksessa ei juuri opeteta, miten suoritus voitaisiin ennakoida tai miten tärkeätä olisi etukäteinen reitin tai maalin hahmottelu. Usein vaihe pyritään sulauttamaan suorituksen yhteyteen, vaikka psykologisesti on kysymys erilaisesta vaiheesta. Sen pedagogisen käsittelyn tulisi tästä johtuen olla myös erilainen.

Näyttää siltä, että ammatillisten kokonaisuuksien ongelma on kehitysvammaisten erityisopetuksessa vaikea myös siksi, että sisäinen mielikuvien muodostus jätetään käsittelemättä tai sitä on erityisen vaikea opettaa. Kuitenkin ilman tämän vaiheen kunnollista pedagogista käsittelyä joudutaan keskittymään suoritukseen, mikä johtaa kehitysvammaisen oppilaan suppeutuvaan ammattitaitoon ja siten rajoittaa hänen ammatillisia mahdollisuuksiaan.

Kokeiluina suuntautumisen ja ennakoivan mielikuvan muodostamisesta ovat itselläni olleet ennen kaikkea vannesahan käyttökokeilut (Hautamäki \& Riikonen 1980; Hautamäki 1979). 
Systemaattisempia kokeiluja ennakoivan mielikuvan muodostamisen didaktisista tavoista ei tiedossani ole muualta. Käytännössä on luonnollisesti ollut syytä enemmän tai vähemmän systemaattisesti käsitellä ongelmaa.

\section{Suorittaminen}

Suoritusvaiheessa muokataan joko käsin, koneella tai ajatuksellisesti työn kohdetta noudattaen työvälineen ja työn kohteen ehtoja. Ulkoisesti toiminta alkaa suoritusvaiheesta. Työkokonaisuuden kannalta ja psykologisesti on kysymys toisesta vaiheesta.

Itse suorituksen muokkaamisesta ei ole nyt syytä käydä tarkempaa erittelyä, koska siihen on yleisestikin kiinnitetty eniten huomiota. On syytä vain suuntautumisvaiheen merkityksen korostamiseksi todeta, että monet huonon tai puuttellisen suorituksen piirteet - taidon suppea-alaisuus, sidonnaisuus vain tietynlaisiin toimintatilanteisiin - syntynevät puutteellisesta suuntautumisesta.

On lisäksi huomattava, että jos työstä erotetaan tavoitteenasettelu ja toiminnan suunnittelu, jäljelle jää vain mekaanisia suorituksia, vaikka ne joskus ovat vaikeitakin. Ei siten ole syytä erittelemättä lähteä siitä, että kehitysvammaisille tai muille supistettuja tavoitteita noudattaville ryhmille opetettaisiin vain tehtäviä, jotka muissa olosuhteissa siirrettäisiin koneiden suoritettaviksi.

Suoritukseen liittyy luonnollisesti monia vaikeuksia, mutta niiden ratkaisu on usein helpohkoa erilaisin rajoittimin, työtahdin vaihtelulla tmv. Tärkeätä on kuitenkin aina varmistaa, että suorituksen puutteet eivät johdu välittömästi suuntautumisen tai tavoitteenasettelun vaikeuksista. Tällaisia ongelmia ei nimittäin voi korjata antamalla lisää tehtäviä, yksinkertaistamalla tilannetta tai muilla itse suoritukseen liittyvillä keinoilla.

\section{Kontrolli ja ohjaus vertailun avulla}

Toiminnan kolmas osa on välitulosten ja lopputuloksen vertaaminen asetettuun tavoitteeseen. Vertailun perusteella suoritetaan tarvittavat korjaukset joko suuntautumisen tasolla tai itse suorituksessa.

Vertailun perusteella toimintaa ohjataan. On tärkeätä havaita, että vertailussa jotain havainnon kohdetta verrataan joko mielikuvaan tai esineelliseen malliin (työpiirros, pienoismalli, standardi). Siten ilman jompaakumpaa toiminnan ohjaus ja korjaus ei juuri ole mahdol- lista. Edellä puhutun suuntautumisvaiheen merkitys ei lopu suorituksen alkaessa, vaan juuri suuntautumisessa on luotava myös korjauksen ja kontrollin psyykkiset edellytykset.

Itsenäiseen, ammatillisesti taitavaan työhön liittyy hyvä kontrollitoiminta. Ammattimies osaa jo varhaisessa vaiheessa arvioida suoritustaan. Erityisesti näyttää siltä, että hän jo suuntautumisvaiheessa läpikäy tilanteen niin huolellisesti, että umpiperään ei suoritusvaiheessa enää jouduta. Tämä aikainen ennakointi on tärkeä osa taitavaa suoritusta. Kehitysvammaisten ammatillisessa opetuksessa kontrolli saa omat ilmenemismuotonsa. Tyypillistä on se, että oppilas arvioi työtään vasta työn loputtua. Työstettävä kohde tai tehtävä työ on saattanut täysin epäonnistua siksi, että työn alussa on tehty pieni virhe, jota ei ole huomattu korjata ajoissa.

Esimerkkejä voidaan löytää sarjatyöstä, jossa virheellinen työtapa, jos sitä ei heti korjata, johtaa helposti kymmenien tai satojen virheellisten tuotteiden syntyyn. Vastaavasti talouskursseilla saattavat mitat olla niin huonosti opittuja, että normaalit virheiden havaitsemismekanismit eivät toimi, ja oppilas saattaa laittaa taikinaan useita isoja kupillisia leivinjauhetta, sokeria tmv.

Tämän ennakoinnin dynamiikan alustavaksi selvittämiseksi on Hautamäen ja Riikosen (1980) teoksessa mainittu rakennustehtävissä sellainen vaihtoehto, että rakennuspalikoiden määrä on virheellinen. Oppilaan on huomattava tämä tai sen näkeminen on usein aivan erityisesti opetettava (s. 54).

Ammatillisessa erityisopetuksessa on siten omana erityiskysymyksenään käsiteltävä sitä, miten kontrollin opetus jaksotetaan ja miten kontrollin toteuttaminen eri vaiheissa opetetaan.

\subsection{Sovellus havaintotoiminnan tarkasteluun}

Suuntautumisteorian esittelyssä tuli esiin havaitseminen aktiivina toimintana, jota on tarvittaessa ohjattava. Havaintotoiminta on alue, jonka psykologinen erittely luo kiinnostavan perustan ammatillisen erityisopetuksen oppimisen ja opetuksen tarkastelulle. Havainnot liittyvät sekä edellä puhuttuun konkreettisuuteen että edellyttävät teoreettisuuden mukaanottoa.

Seuraavassa esityksessä pyritään yhdistämään suuntautumisteoria ja Ulric Neisserin käsityksiä (Neisser 1976). Tavoitteena on laajentaa psykologista perustaa ja osoittaa, että samantapaisia otteita on muitakin. Useimmat näyttävät johtavan yhtenäiseen kuvaan op- 
pimis- ja opetusprosessin suhteista: oppimista on tarkasteltava vaiheittaisena, kehittyvänä, korjautuvana tapahtumana, joka liittyy jonkin todellisuuden alueen omaksumiseen ja tiedon käyttöön. Tapahtumaan voidaan myös vaikuttaa systemaattisilla toimenpiteillä; vaikuttamisen syvyydestä vallitsee erilaisia käsityksiä.

Havainnossa ei ole vain kysymys visuaalisesta tai näköhavainnosta, vaan periaatteessa kaikenlaisen informaation koodauksesta ja tulkinnasta. Havainto on aina aktiivi, monimutkainen psyykkinen tapahtuma, joka riippuu, paitsi havaittavasta asiasta, myös havaitsijan taidoista, kokemuksista ja odotuksista.

Esimerkki, jossa on mukana myös kehitystä, on geometristen muotojen havaitseminen älykkyystesteihin sisältyvässä palikkatehtävässä. Lapselle palikan ja kolon muodon yhteensovittaminen on hidas tapahtuma, jossa motorisilla komponenteilla - kokeilulla - on tärkeä sija. Lapsi ei tietyssä vaiheessa todellakaan 'näe', että tuossa on kolmiopalikka ja tuossa kolmiokolo, joka on kooltaankin sopiva ja johon palikka mahtunee. Lapselle palikkatehtävä on vielä mielenkiintoinen. Kun itse havainto on muuttunut automaattiseksi havainnoksi menettää tehtäväkin yksinkertaisessa muodossaan kiinnostavuutensa.

Havainnossa koodataan tuleva informaatio. Koodaukseen osallistuvat myös käsitteet ja kieli eikä inhimillinen havaintotoiminta tapahdu koskaan ilman kielen osallistumista (Luria 1973, 230). Lapsi oppii vähitellen käsitteellisen kehityksen avulla ohjaamaan omaa havaintotoimintaansa, joka oltuaan alussa hidas ja monivaiheinen muuttuu nopeaksi ja yhtäaikaiseksi. Tässä yhteydessä käytetään joskus käsitteitä sukkessiivinen eli jonollinen ja simultaaninen eli yhtäaikainen käsittely. Havaintotoiminnassa jonollinen, eli yksi seikka kerrallaan työstävä katselu muuttuu useita seikkoja yhtäaikaa tunnistavaksi. Tämän prosessin pedagoginen käsittely ja muodostus on vaikeata, mutta mahdollista.

Havaintotoiminnan suuntautumisvaiheesta on mahdollista puhua ja pedagogisen käsittelyn kannalta sen olemassaolo on havainnon opettamisen perusta. Oppilaat on opetettava havaitsemaan tietyt asiat.

Esimerkkejä voisivat olla kuulosuojaimien käytön opettaminen, jossa oppilaiden on alussa vaikea havaita työsalissa muista ja itsestään ovatko kuulosuojaimet käytössä. Seikan havaitseminen on aina erikseen ennen työsaliin menoa tuotava esiin. Vähitellen tilanne on sellainen, että oppilaat havaitsevat erilaisista kuvistakin turvallisen tilanteen tai suojaimien puutteet.

Toinen esimerkki on työsalin siivottomuuden/ puhtauden havaitseminen, joka sekin on erikseen opetettava. Aikanaan asiantilan havaitseminen nopeutuu ja automaatistuu.

Kolmantena esimerkkinä on laitossiivoojien ammatillisessa erityisopetuksessa havaittu kiinnostava ongelma: miten oppilaat oppisivat havaitsemaan tahran. Sen havaitseminen on mm. siksi tärkeätä, että jos sitä ei havaita, niin työ jää joko kesken tai sitä on tehtävä liikaa ja puhdistettava esimerkiksi jo puhdistetut alueet.

Toiminnan suuntautuminen - nyt havaittavan asian tunnusmerkkien etsiminen ja tunnistaminen - levittäytyy tai avautuu uudestaan, jos tehtävä vaikeutuu. Suuntautumista ohjaa kuitenkin havaitsijan odotus tällaisessa tilanteessa eikä kyseessä siten ole satunnainen tapahtuma.

Havaintotoiminnan käsitettä voidaan käyttää, koska havainnolla on psykologinen rakenne. Siitä on esittänyt olettamuksiaan $\mathrm{mm}$. Neisser, jonka havaintosyklin malli on seuraavan esityksen perustana.

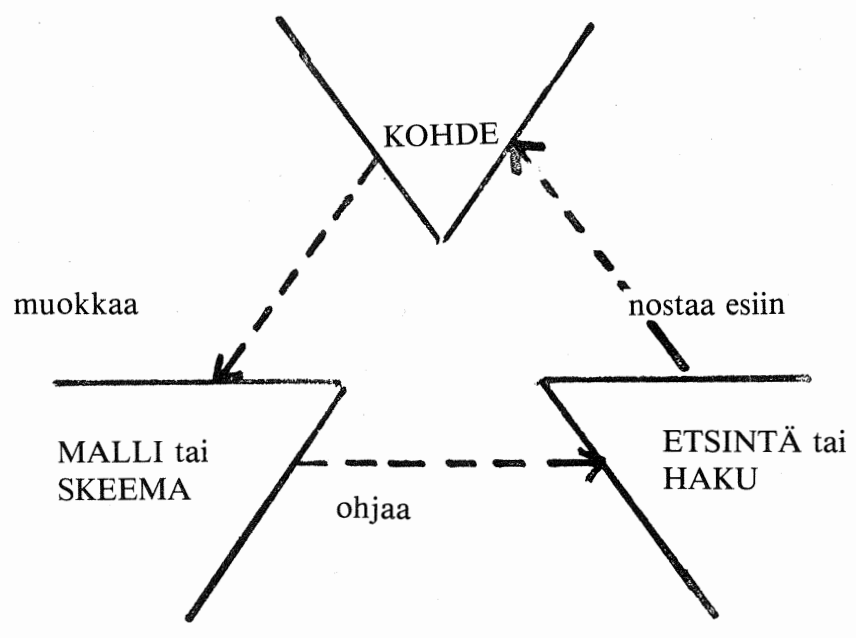


Havainnolle oleellisia ovat ne ennakoivat mallit, jotka ohjaavat havaitsijan hyväksymään tietyntapaista informaatiota ja siten kontrolloivat katselua. Kunakin hetkenä havaitsija näyttää muodostavan informaatio-odotuksia, jotka tekevät mahdolliseksi hyväksyä informaatio. Usein informaation esilletuloon liittyy sen aktiivi etsintä. Esimerkkeinä ovat silmien liikuttelu, pään kääntely tai muu etsintä. Tätä ohjaavat ennakoivat mallit, jotka ovat näin havaintotoiminnan suunnitelmia ja samalla virittäytymistä tietynlaiseen tilanteeseen. Selvittelyn tulos puolestaan muokkaa lähtökohtana ollutta mallia. Havaitseminen on käsite, joka tarkoittaa koko sykliä, ei vain sen yksittäistä osaa.

Vaikkakaan havaintotoimintaa ei voida sijoittaa havaintosyklin tiettyyn osaan, on malli tarkasteltavissa laajemminkin.

Mallit voidaan tietyissä olosuhteissa erottaa niistä sykleistä, joiden osia ne alunperin ovat olleet. Neisserin käsityksen mukaan tällainen irroittaminen on kaikkien korkeampien henkisten toimintojen perusta. Silloin niistä käytetäänkin jo muita nimityksiä; puhutaan mielikuvituksesta, suunnittelusta ja tarkoittamisesta/tahtomisesta.

Esitetty havaintosykli ei estä ennakoimattoman informaation havaitsemista. Odottamaton ärsyke käynnistää varsinaisen havaintotoiminnan. Tilanteessa on yleensä riittävästi informaatiota syklin pyöräyttämiseksi ja ylläpitämiseksi. Kuitenkaan jos ärsykettä ei ole ennakoitu taikka siitä ei saada käyntiin havaintosykliä, ärsykkeellä on vain rajallinen ja lyhytkestoinen vaikutus.

Havaintosyklin pyöräyttämisen helppous erottaa usein kehitysvammaiset normaaleimmista havaitsijoista. Kehitysvammaisten älyllisen toiminnan puutteet liittyvät usein juuri henkisten toimintojen hitauteen ja valmiiden skeemojen raskasliikkeisyyteen ja hitauteen. Aikuisten ihmisten älykkyyden arviointiin käytetyssä testistössä on tehtäväsarja, jossa on havaittava piirretyistä kuvista puuttuvat osat. $\mathrm{Ne}$ voivat olla joskus lehmän yhden jalan sorkka, joskus silmälasien toinen sanka. Puuttuvat kohdat on löydettävä nopeasti, mikä edellyttää että kuvaan 'heitetään' useita nopeita tarkistuskierroksia: laske sormet, tarkista jalat, katso auringon suunta, jne. Näiden on oltava valmiina käyttöön, muuten tehtävästä ei suoriudu hyvin.

Toinen havaintosykliin ja havaitsemiseen liittyvä keskeinen piirre on useiden aistipiirien informaation yhdistäminen. Ihmisen toiminta edellyttää muitakin kuin näköhavaintoja. Tämän mukaisesti aikuisen ihmisen havainnon mallit/skeemat eivät ole virittäytyneitä yksinomaan näköinformaation vastaanottamiseen tai kuulo- tai kosketusinformaation vastaanottoon, vaan ne liittyvät havaitsemiseen yleisesti, ovat perseptuaalisesti virittyneitä. Jonkintapahtuman havaitseminen merkitsee kaikenlaisen informaation hakua, käyttä ja yhdistämistä: ' Kun olemme kuulleet jotain, katsomme mitä se on, ja katselemisen tulos vaikuttaa puolestaan siihen kuinka sijoitamme ja tulkitsemme kuulemamme", (Neisser 1976, 30).

\section{Kohti käytäntöä}

\subsection{Ennakoinnin opettamisesta}

Havaintotoimintojen ja sitä edeltänyt suuntautumisteorian käsittely toi esiin $\mathrm{mm}$. ennakoinnin. Ennakointi on ehkä selvimmin taitavan työn määrittelevä piirre, koska se ylittää pelkän suorituksen, oli suoritus sitten miten vaativa tai monimutkainen tahansa. Ennakoiminen on samalla alue, jonka psykologis-pedagoginen käsittely on mahdollista ja siten tarjoaa keinon lähestyä taitavan työn muodostamisen tavoitetta ja tehtävää. Kehitysvammaisten kohdalla ennakoiminen on alue, jonka tietoisesta kehittämisestä ei näytä kirjallisuudessa juuri olevan mainintoja.

Tutkittaessa kehitysvammaisten erityiskurssilla olevien oppilaiden toimintaa vannesahan yhteydessä havaittiin, että he eivät todellakaan nähneet sitä miten sahanterä kulkisi. Heidän havaintonsa kohdistui vain terän ja työstettävän kappaleen yhteiseen rajaan. Näin he joutuivat tilanteisiin, joissa terä juuttui paikoilleen. Tilanteeseen ei saatu parannusta muutoin kuin siirtämällä oppilaat aluksi kynä ja paperitehtävien pariin luokkahuoneeseen, jossa he joutuivat erittelemään erilaisia kuvia. Esimerkkeinä olivat Hautamäen ja Riikosen harjoitustehtäväkirjan monet tehtävät, joita käytettiin. Tämän jälkeen palattiin työsaliin kynän kanssa. Vannesahalla työstettäviin kappaleisiin piirrettiin näkyviin ennakointiviivat eli ns. apuviivat, jotka on sahattava ennen varsinaista sahausta (kts. Hautamäki \& Riikonen 1980, 66-68; Hautamäki 1979).

Näyttää yleisesti siltä, että ennakoinnin tutkimisella voidaan päästä suuntautumisen tutkimuksessa ainakin oppimisen psykologian ja opetuksen kehittämisen alueella uusiin kysymyksiin. 


\subsection{Oppimisvaikeuksien tunnistaminen}

Jaksoissa 1. ja 2. esitettyjä asioita voidaan pyrkiä tiivistämään oppimisen vaikeuksien tunnistamiskaavioon. Tällaiset kaaviot sisältävät aina tiettyjä yksinkertaistuksia, mutta ne tähtäävätkin tilanteen eri puolien harkinnan mahdollistamiseen tarkemman erittelyn perustaksi.

Tällaisia oppimisvaikeuksien vianetsintäkaavioita on erilaisia ja ohessa esiteltävä on mukailtu Whelan ja Speaken esittämästä (Whelan \& Speake 1979) ryhmittämällä ja täydentämällä suuntautumisteorian avulla.

\section{Yleisedellytykset}

1. Onko oppijan olo mukava?

2. Onko oppija vireillä ja hereillä? Hän ei ole lääkekuurilla?

3. Onko varmistettu, että taustamelu ei ole liian kova eikä näköhoukuttimia ole liikaa?

4. Onko varmistettu, että oppija haluaa suorittaa tehtävän? Onko selvitetty, että samanaikaisesti ei ole käynnissä oppijaa enemmän kiinnostavaa tapahtumaa?

\section{Suuntautumisedellytykset}

5. Onko tehtävä selvitetty oppijalle, tietääkö hän mitä hänen pitää tehdä, onko lopputavoite selvillä?

6. Osaako hän kiinnittää huomionsa oikeaan piirteeseen oikea-aikaisesti? Tietääkö hän mihin hänen pitää tarkkaavaisuutensa kohdistaa, tietääkö hän toimintajärjestyksen?

\section{Suoritusedellytykset}

7. Kykeneekö oppija vaadittuun näkemiseen, kuulemiseen, motoriseen koordinaatioon, voimankäyttöön?

8. Osaako hän muutoin tehtävän suorituksen, onko hän vielä epävarma osaamisestaan, liittyykö suorittamiseen erityisiä vaikeuksia, jotka tekevät oppijan epävarmaksi, haluttomaksi, pelokkaaksi?

\section{Kontrolliedellytykset}

9. Tietääkö hän mihin tulee suorituksen aikana kiinnittää huomiota, tietääkö hän miten tulee katsoa, kosketella, kuunnella? Tietääkö hän milloin suoritus on oikein, onko hänelle selvinnyt tarkka kuva lopputilan luonteesta?

10. Osaako hän keskeyttää toiminnan virheen sattuessa? Osaako hän kääntyä työnopettajan/-ohjaajan puoleen, jos asiat eivät mene niinkuin niiden pitäisi mennä?

11. Muistaako hän mitä tulee suorittaa tietyn vaiheen jälkeen? Onko hän selvillä toimin- nan jaksotuksesta ja yhden vaiheen päättymisen kriteereistä, uuden vaiheen aloittamisen ehdoista?

Kehitysvammaisten työtoiminnoissa aivan erityinen piirre on toiminnan outo kaksijakoisuus: joko toimintaa jatketaan 'päättömästi' tai sitten uutta vaihetta ei osata itsenäisesti alkaa. Usein psykologisena perusteena näyttää olevan se, että työntekijälle ei ole opetettukaan sitä, mistä hän tietäisi työn tulleen suoritetuksi tai milloin hän voi alkaa uuden työvaiheen.

\subsection{Ammatillisen toiminnan kokonaisuus}

Lopuksi on korostettava sitä, että ammatillinen toiminta on kuitenkin kokonaisuus. Kysymyksessä on koko persoonallisuuden toiminta. Vaikka pedagogisesti ja didaktisesti on usein perusteltua keskittyä erittelemään joidenkin konekokonaisuuksien hallinnan edellytyksiä, niin ammatillisen koulutuksen on tähdättävä muuhunkin.

Ammatillisen toiminnan kokonaisuus edellyttää opetuksessa huomiota kiinnitettävän työyhteisön kehittämiseen. Kehitysvammaisten kohdalla on aihetta usein seurata myös vapaa-ajan kulkua ja tarvittaessa opastaa oppilaita sielläkin.

Näiden seikkojen pedagogiseen käsittelyyn ei tässä yhteydessä kuitenkaan syvennytä.

\section{Lopuksi}

Tarkoituksena on ollut esittää ammatillisen erityisopetuksen didaktisen ja pedagogisen kehittelyn perustaksi eräitä lähtökohtia. Osaa niitä on syvennetty ja esitetty kriteereitä omaehtoiselle syventämiselle ja kokeilulle. Tärkeätä on ollut yhtäältä ammatillisen toiminnan kokonaisuuden korostus ja toisekseen tuon kokonaisuuden 'purkaminen' psykologisen teorian avulla pedagogisesti järkeviksi pedagogisen työn kohteiksi.

Tuo purkukokeilu on samalla tuonut esiin, että psykologisen otteen ja pedagogisen otteen on oltava läheisessä kontaktissa, vaikka ne kohdistuvat oppilaan toiminnan eri puoliin. On ilmeistä, että oppimisen prosessien tunteminen edesauttaa opetuksen suunnittelua opetussuunnitelman kehittelyä - ja opettamista; vastaavasti opetuksen tilanne, jossa oppilas pyritään johdattamaan tiettyyn tavoitteeseen, antaa psykologiselle tutkimukselle ja sovellukselle selkeät kriteerit ja tehtävän. 


\section{Lähteet:}

Galperin, P.J. 1980. Johdatus psykologiaan. Helsinki: Kansankulttuuri.

Hautamäki, J. 1978a. Psykologian ja pedagogiikan suhteesta. Psykologia, 13, 1, 2-9.

Hautamäki, J. 1978b. Koulutettavuus ja opetettavuus. Kahden koulutuspsykologian peruskäsitteen tarkastelu. Joensuun korkeakoulu, Kasvatustieteiden osaston julkaisuja no 8.

Hautamäki, J. 1979a. Vammaisten ammatillinen norlisaatio - tutkimustulosten tarkastelua. Ketju, $15,4,8-11$.

Hautamäki, J. 1979b. Galperininteoria oppimisesta ja opetus. Koulutyöntekijä, 7, 5-6, 24-26.

Hautamäki, J., Riikonen, J. 1980. Taitavaan suoritukseen. Kehitysvammaliitto r.y: Valtakunnallisen tutkimus- ja kokeiluyksikön julkaisuja 3/1980

Häyrynen, Y.-P., Hautamäki, J. 1977. Människans bildbarhet och utbildningspolitiken. Stockholm: Wahlström \& Widstrand.

Leontjev, A.A. 1979. Kieli ja ajattelu. Helsinki: Kansankulttuuri.

Luria, A.R. 1973. Working brain. Harmonds worth: Penguin Books.

Mikkonen, V., Keskinen, E. 1980. Sisäisten mallien teoria liikennekäyttäytymisessä. Helsingin yliopisto, Yleinen psykologia, General Psychology Monographs no B 1 .

Neisser, U. 1976. Cognition and reality. Principles and implications of cognitive psychology. San Fransisco: W.H. Freeman.

Singleton, W.T. (toim.) 1978. The study of real skills. Volume 1: the analysis of practical skills. Lancaster: MTP Press.

Whelan, E., Speake, B. 1979. Learning to cope. London: Souvenir Pre.

Youngman, M., Oxtoby, R., Monk, I.D., Heywood, I. 1978. Analysing jobs. Westmead: Gower Press. 